\title{
EVROPSKÉ DOTAČNÍ ZDROJE PRO MALÉ A STŘEDNÍ PODNIKY
}

\author{
Jan Urbánek
}

\section{Klíčová slova:}

Evropská unie, rámcový operační program, operační program, prioritní osa, oblast podpory, primární finanční pomoc, sekundární finanční pomoc.

\section{Key words:}

European Union, framework operational programme, operational programme, priority axis, support area, primary financial help, secondary financial help.

\begin{abstract}
Abstrakt
Česká republika má možnost v rámci evropských dotačních zdrojů čerpat finanční pomoc na realizaci rozvojových projektů. Dotační zdroje jsou strukturovány na celoevropské, národní a regionální úrovni. Část dotačních zdrojů je věnována problematice rozvoje a podpory MSP. Článek se zabývá klíčovými dotačními zdroji, do nichž mohou české MSP a organizace podporující MSP předkládat své projektové záměry a žádat tak o finanční pomoc.
\end{abstract}

\begin{abstract}
The Czech Republic has the possibility to utilize financial sources on development projects in the frame of European subsidy sources. Subsidy sources are structured on the all-European, national and regional level. A part of subsidy sources is focused on the theme of support and development of SME's. The paper deals with the key subsidy sources to which can SME's and organisations supporting SME's submit their development projects and thus claim for the financial help.
\end{abstract}

\section{Úvod}

Evropská unie vytvořila rozsáhlou sít' dotačních zdrojů, z nichž mohou čerpat finanční pomoc všechny členské země EU a některé přidružené země, z nimiž má EU uzavřeny dvoustranné smlouvy o spolupráci. Tyto dotační zdroje jsou geograficky i tematicky strukturovány do komunitárních programů, strukturálních fondů, rámcových programů pro vědu a výzkum a operačních programů. Komunitární programy a rámcové programy pro vědu a výzkum jsou přístupny všem členským zemím EU, operační programy jsou pak vytvořeny pro konkrétní členskou zemi EU a žádat o finanční podporu mohou žádat pouze subjekty nacházející se na území dané členské země. $\mathrm{V}$ rámci široké palety témat, jež jsou v rámci těchto dotačních zdrojů řešeny, nechybí tematika podpory hospodářského rozvoje zaměřená na malé a střední podniky (dále jen MSP).

\section{Metodika a cíl}

Vzhledem k tomu, že dotační struktura EU obsahuje zhruba 2300 různých dotačních zdrojů, stala se velmi nepřehlednou pro potenciální žadatele o dotaci. Problémy s touto nepřehlednou strukturou mají především MSP, které do systému vstupují většinou jen jedenkrát na rozdíl od veřejnoprávních institucí. Cílem tohoto článku je, na základě provedeného výzkumu a použitých metod, poskytnout zevrubný přehled dotačních zdrojů, které jsou věnovány problematice podpory a rozvoje MSP a kde mohou MSP a organizace zastřešující MSP 
uplatnit své projektové záměry. Použitá metodika výzkumné práce se opírá o dosavadní výsledky teoretického i empirického bádání. V rámci metodiky byly použity metody a techniky, které jsou příznačné pro vstupní orientaci ve zkoumané problematice. Konkrétně se jednalo o metodu analýzy (analyzovány byly primární i sekundární informační zdroje v podobě oficiálních zpráv a vyjádření řídících orgánů a zprostředkujících subjektů a prováděcí dokumentaci jednotlivých dotačních zdrojů), metodu syntézy (byla prováděna zejména ve vyhodnocování, interpretacích, rekomendacích, návrzích a všude tam, kde byly shrnuty výsledky primárního i sekundárního šetření), metodu analogie (v porovnávaných a zkoumaných dotačních zdrojích byly zjišt'ovány vedle shodných problémů i velmi rozdílné poznatky), metodu srovnání (použitím této metody bylo umožněno vyabstrahovat shody a rozdíly), metodu dedukce (vzhledem k tomu, že bylo vycházeno z evropského, národního a regionálního rámce, bylo nutno vždy dedukovat do nižších poloh problematiky) a metodu abstrakce.

\section{Výsledky výzkumu}

Základním celoevropským dotačním zdrojem řízeným přímo Evropskou komisí je Rámcový program pro konkurenceschopnost a inovace, který se zaměřuje hlavně na MSP, podporuje inovační činnosti (včetně ekologických inovací), zajišt'uje lepší přístup $\mathrm{k}$ finančním prostředkům a poskytuje služby na podporu podnikání v regionech. Podněcuje lepší zavádění a využívání informačních a komunikačních technologií a přispívá k rozvoji informační společnosti. Kromě toho podporuje zvýšené využívání obnovitelných zdrojů energie a energetickou účinnosti. ${ }^{1}$ Rámcový program pro konkurenceschopnost a inovace probíhá od roku 2007 do roku 2013 a jeho celkový rozpočet činí 3621 milionů eur. Je rozdělen na tři operační programy, každý program má své specifické cíle, které mají přispět ke konkurenceschopnosti podniků a ke schopnosti inovace v jejich vlastních oblastech působnosti, jako jsou např́ílad informační a komunikační technologie nebo udržitelná energie: Program pro podnikání a inovace, Program na podporu politiky informačních a komunikačních technologií, Program Inteligentní energie pro Evropu.

Analýzou prováděcí dokumentace výše uvedených dotačních zdrojů však bylo zjištěno, že výzvy k předkládání projektů do těchto dotačních zdrojů nejsou určeny přímo pro MSP, žadateli mohou být pouze veřejnoprávní subjekty a komerční subjekty, jako např. banky, pojištovny, leasingové společnosti apod. v jednotlivých členských státech, které následně tyto finanční nástroje poskytují MSP. V tomto případě se tedy nejedná o přímou podporu MSP z dotačních zdrojů EU, ale o nepřímou podporu skrze veřejnoprávní a komerční prostředníky v jednotlivých členských státech EU.

V rámci následujících dvou dotačních zdrojů mohou MSP realizovat projekty za účasti mezinárodních partnerů. Prvním je Operační program Nadnárodní spolupráce je rozdělen do několika zón. Česká republika patří do zóny Střední Evropa a Operační program Nadnárodní spolupráce sdílíme s Rakouskem, Polskem, částí Německa, Mad'arskem, Slovinskem, Slovenskem, částí Itálie a z nečlenských zemí s částí Ukrajiny. Operační program Nadnárodní spolupráce spadá mezi operační programy v cíli Evropská územní spolupráce a pro Českou republiku je v něm vyčleněno 37,46 mil. $€$, což činí přibližně $0,14 \%$ veškerých prostředků určených $\mathrm{z}$ fondů EU pro Českou republiku. Zaměřuje se na spolupráci mezi veřejnými orgány a institucemi s charakterem veřejných orgánů s cílem výměny a přenosu zkušeností především v oblastech inovací, dopravní dostupnosti, životního prostředí a zvyšování atraktivity měst a regionů. Účelem spolupráce je zajištění dostupnosti znalostí a nástrojů pro vytváření partnerství, aby se předešlo zbytečnému opakování činností a objevování již

\footnotetext{
${ }^{1}$ Rámcový program pro konkurenceschopnost a inovace, http://ec.europa.eu/cip/index_cs.htm
} 
objeveného. Podporováno je vytváření partnerství a sítí podporujících dosahování konkrétních výstupů a výsledků, které přímo vedou ke konkrétním budoucím iniciativám a investicím. Operační program obsahuje 5 priorit rozdělujících operační program na logické celky, a ty jsou dále konkretizovány prostřednictvím tzv. oblastí intervence, které vymezují, jaké typy projektů mohou být $\mathrm{v}$ rámci př́islušné prioritní osy podpořeny. MSP mohou uplatnit své projekty v rámci prioritní osy 1 - Podpora inovace ve Střední Evropě. Jedná se např. o podporu nadnárodních klastrů $\mathrm{v}$ klíčových kompetenčních oblastech, společný vývoj a implementaci inovačních strategií $\mathrm{v}$ nadnárodních oblastech, spolupráci inkubátorů v regionech, kde upadá průmysl, budování nadnárodních sítí mezi institucemi terciárního vzdělávání a výzkumnými institucemi, podpora nadnárodní spolupráce mezi školicími zařízeními a organizacemi působícími na trhu pracovních sil, budování a zdokonalování nadnárodních vzdělávacích a školicích sítí ve vyšším či celoživotním vzdělávání apod. Bližším zkoumáním Prováděcího dokumentu Operačního programu a Aplikačního manuálu bylo zjištěno, že subjekty oprávněnými předkládat projektové žádosti jsou pouze národní, regionální a lokální veřejnoprávní instituce a dále pak tzv. public equivalent bodies, což jsou subjekty založené na základě veřejného práva za účelem zajišt’ování veřejného zájmu, a jež jsou zároveň financovány převážně z veřejných zdrojů. MSP v rámci tohoto operačního programu nemohou vystupovat jako předkladatelé projektových záměrů (vedoucí partneři) ani jako formální projektoví partneři. Jedinou možností MSP, jak se zapojit do realizace projektů kofinancovaných z tohoto operačního programu, je působit $\mathrm{v}$ roli subkontraktora a dodavatele služeb. Zde se však MSP dostávají do prostř̌edí veřejných zakázek, jež jsou vyhlašovány veřejnoprávními subjekty realizujícími projekty. Veřejnoprávní subjekty nemohou př́mo vyzvat ke spolupráci konkrétní vhodné MSP, ale musí se řídit Zákonem č. 137/2006 Sb., o veřejných zakázkách. Vzhledem ke složitosti a časté neprůhlednosti těchto veřejných zakázek MSP ztrácejí zájem o vstup do rozvojových projektů kofinancovaných z veřejných zdrojů EU a státního rozpočtu a další aktivity v tomto směru nevyvíjejí.

Druhým dotačním zdrojem pro realizaci mezinárodních projektů MSP je Operační program Meziregionální spolupráce, jež je společný pro všechny členské státy EU, Norsko a Švýcarsko. ${ }^{2}$ Operační program Meziregionální spolupráce spadá mezi operační programy v cíli Evropská územní spolupráce a je pro něj z fondů EU vyčleněno 321,32 mil. €. České veřejné zdroje se podílejí na financování programu částkou 0,17 mil. €. V rámci programu neexistuje specifická finanční alokace pro jednotlivé země. Zaměřuje se na spolupráci mezi veřejnými orgány a institucemi s charakterem veřejných orgánů na regionální a místní úrovni s cílem výměny a přenosu zkušeností a zajištění společného rozvoje přístupů a nástrojů, které zlepší účinnost politiky regionálního rozvoje. Hlavními oblastmi spolupráce jsou inovace a znalostní ekonomika, životní prostředí a ochrana před riziky. V projektech je možno zaměřit se na aktivity, jako např. strategická spolupráce pro optimalizaci a zvýšení využívání nových technologií přátelských k životnímu prostředí, výměna zkušeností při restrukturalizaci regionů závislých na tradičním průmyslu, shromáždění a přenos dobrých zkušeností na vědecké parky, inovační centra, podnikatelské inkubátory nebo klastry, spolupráce v oblasti finanční pomoci malým a středním podnikům a v oblasti rozvoje rizikového kapitálu, podpora ekonomické diversifikace venkovských oblastí, výměna informací o vývoji veřejných služeb založených na informačních a komunikačních technologiích pro zvýšení efektivnosti a konkurenceschopnosti obchodu a podnikání, výměna nejlepších postupů při zaškolování a udržení výzkumných pracovníků, společné aktivity pro zlepšení pracovního trhu. Bohužel, při bližším zkoumání Prováděcího dokumentu Operačního programu a Aplikačního manuálu bylo opět zjištěno, že subjekty oprávněnými předkládat projektové žádosti jsou pouze národní,

\footnotetext{
${ }^{2}$ Operační program Meziregionální spolupráce, http://www.strukturalni-fondy.cz/getdoc/f7d48c79-532a-407ab373-95bd79035231/OP-Meziregionalni-spoluprace
} 
regionální a lokální veřejnoprávní instituce a public equivalent bodies. Situace je zde tedy naprosto shodná jako u Operačního programu Nadnárodní spolupráce, MSP nemohou př́ímo vstupovat do rozvojových projektů a z primární finanční pomoci jsou tedy vyloučeny. Podmínky jsou tedy nastaveny tak, že veřejný sektor pomocí dotační politiky financuje opět veřejný sektor. Nabízí se zde tedy otázka, proč tvůrci koncepce dvou výše zmíněných dotačních zdrojů z rozvojových projektů naprosto vyloučili MSP, které jsou v naprosté většině př́ípadů nositeli a iniciátory nových, inovativních myšlenek a postupů, které by oblast podpory MSP posunuly dále v rámci konkurenceschopnosti evropské ekonomiky.

Samostatnou skupinou dotačních zdrojů, v rámci kterých je možno realizovat dvojstranné projekty, jsou Operační programy přeshraniční spolupráce. Konkrétně mohou být projekty tematicky zaměřené na MSP realizovány v následujících programech.

Tabulka č. 1: Prioritní osy a oblasti podpory věnované problematice MSP.

\begin{tabular}{|l|l|l|}
\hline Operační program & Prioritní osa & Oblast podpory \\
\hline $\begin{array}{l}\text { Přeshraniční spolupráce Česká } \\
\text { republika - Polská republika } 2007 \\
\text { - } 2013\end{array}$ & $\begin{array}{l}\text { Podpora rozvoje } \\
\text { podnikatelského prostředí a } \\
\text { cestovního ruchu }\end{array}$ & $\begin{array}{l}\text { Rozvoj } \\
\text { podnikatelského } \\
\text { prostředí }\end{array}$ \\
\hline $\begin{array}{l}\text { Přeshraniční spolupráce } \\
\text { Slovenská republika - Česká } \\
\text { republika } 2007 \text { - } 2013\end{array}$ & $\begin{array}{l}\text { Podpora sociokulturního a } \\
\text { hospodářského rozvoje } \\
\text { příhraničního regionu a } \\
\text { spolupráce }\end{array}$ & $\begin{array}{l}\text { Rozvoj } \\
\text { podnikatelského a } \\
\text { inovačního prostředí }\end{array}$ \\
\hline $\begin{array}{l}\text { Přeshraniční spolupráce Rakousko } \\
\text { - Česká republika } 2007 \text { - 2013 }\end{array}$ & $\begin{array}{l}\text { Socioekonomický rozvoj, } \\
\text { cestovní ruch a transfer know- } \\
\text { how }\end{array}$ & $\begin{array}{l}\text { Infrastruktura a služby } \\
\text { spojené s podnikáním a } \\
\text { inovacemi }\end{array}$ \\
\hline $\begin{array}{l}\text { Přeshraniční spolupráce Česká } \\
\text { republika - Svobodný stát } \\
\text { Bavorsko 2007 - 2013 }\end{array}$ & $\begin{array}{l}\text { Hospodářský rozvoj, lidské } \\
\text { zdroje a sítě }\end{array}$ & $\begin{array}{l}\text { Hospodářská } \\
\text { spolupráce a rozvoj } \\
\text { ekonomického sektoru }\end{array}$ \\
\hline $\begin{array}{l}\text { Program na podporu přeshraniční } \\
\text { spolupráce mezi Českou } \\
\text { republikou - Svobodným státem } \\
\text { Sasko 2007 - 2013 }\end{array}$ & $\begin{array}{l}\text { Rozvoj hospodářství a } \\
\text { cestovního ruchu }\end{array}$ & $\begin{array}{l}\text { Hospodářská } \\
\text { kooperace a rozvoj } \\
\text { příhraničních } \\
\text { hospodářských struktur }\end{array}$ \\
\hline
\end{tabular}

Zdroj: Přeshraniční Operační programy ČR.

Při hlubším zkoumání výše uvedených dotačních zdrojů bylo zjištěno, že názvy předmětných prioritních os a oblastí podpory sice signalizují možnost předkládání projektů privátními MSP, ve skutečnosti je však tato možnost nulová. Ke každému Operačnímu programu je zpracována prováděcí dokumentace $\mathrm{v}$ podobě metodických př́ruček pro žadatele a příjemce dotace. Detailní analýzou kompletní prováděcí dokumentace všech zmíněných operačních programů bylo zjištěno, že subjekty oprávněnými předkládat projekty do těchto Operačních programů jsou výhradně subjekty veřejnoprávního nebo neziskového charakteru. Jako př́íklad cituji z Operačního programu přeshraniční spolupráce Rakousko - Česká republika 2007 - 
2013: „V rámci tohoto programu nebude poskytována podpora podnikatelským subjektům a soukromé podniky nemohou o podporu žádat “3. Jako další př́iklad uvádím tabulku č. 2, jež tvoří přílohu Operačního programu přeshraniční spolupráce Slovenská republika - Česká republika $2007-2013$.

Tabulka č. 2: Oprávnění žadatelé v rámci Operačního programu přeshraniční spolupráce Slovenská republika - Česká republika 2007 - 2013.

\begin{tabular}{|l|l|l|}
\hline Oprávněný žadatel & Relevantní legislativa & Sektor \\
\hline Státní podnik & $77 / 1997$ & veřejný \\
\hline $\begin{array}{l}\text { Akciová společnost - min. 80\% podíl } \\
\text { veřejnoprávních osob na základním kapitálu a } \\
\text { min. 80\% podíl veřejnoprávní právnické osoby na } \\
\text { hlasovacích právech }\end{array}$ & & \\
\hline $\begin{array}{l}\text { Společnost s ručením omezeným - min. 80\% } \\
\text { podíl veřejnoprávních osob na základním kapitálu } \\
\text { a min. 80\% podíl veřejnoprávní právnické osoby } \\
\text { na hlasovacích právech }\end{array}$ & $513 / 1991$ & \\
\hline
\end{tabular}

Z obou výše uvedených příkladů je zřejmé, že privátní MSP se nemohou rozvojových projektů účastnit, tzn. jak v roli žadatele o dotaci podávat projektové záměry, tak i v roli projektového partnera participovat na realizaci projektu. Jsou tedy absolutně vyloučeny z primární finanční pomoci. Jedinou možností, jak z prostředků Operačních programů Evropské územní spolupráce podpořit privátní MSP, je využití tzv. sekundární finanční pomoci. Jedná se o př́pady, kdy veřejnoprávní organizace realizují projekty, ve kterých mohou nepřímým způsobem nějakou formou podpořit rozvojové aktivity MSP. Těmito subjekty může být stát a jeho organizační složka, územně samosprávný celek, příspěvková organizace, zájmová sdružení a obecně prospěšné organizace. Podpora privátních MSP se tedy dostala výlučně do rukou veřejnoprávních subjekti̊ a záleží pouze na ochotě těchto veřejnoprávních subjektů, zda budou pro MSP realizovat rozvojové projekty. Z výčtu subjektů oprávněných podávat rozvojové projekty zaměřené na MSP v rámci Operačních programů Evropské územní spolupráce je zřejmé, že možným žadatelem může být Hospodářská komora ČR, případně zájmové sdružení zastř̌šující určitý segment MSP. Dle dosavadních výsledků čerpání finanční pomoci z prostředků Operačních programů Evropské územní spolupráce zaměřených na MSP je zřejmé, že ze strany subjektů oprávněných podávat rozvojové projekty není velký zájem. Jednou z prŕčin nezájmu je i samotný finanční mechanismus fungující na základě tzv. předfinancování ze strany žadatele o dotaci, kdy žadatel nejdříve financuje projektové aktivity z vlastních zdrojů a až zpětně může žádat poskytovatele dotace o proplacení výdajů. Situaci dokumentuje tabulka č. 3, která uvádí aktuální přehled čerpání oblastí podpory věnovaných problematice MSP v přeshraničních operačních programech ČR.

\footnotetext{
${ }^{3}$ Operační program přeshraniční spolupráce Rakousko - Česká republika 2007 - 2013, http://www.at-cz.eu/atcz/cz/1_program.php
} 
Tabulka č. 3: Aktuální přehled čerpání oblastí podpory věnovaných problematice MSP v přeshraničních operačních programech ČR.

\begin{tabular}{|l|l|c|}
\hline Operační program & Oblast podpory & Zbývající alokace \\
\hline $\begin{array}{l}\text { Přeshraniční spolupráce Česká } \\
\text { republika - Polská republika 2007 } \\
-2013\end{array}$ & $\begin{array}{l}\text { Rozvoj podnikatelského } \\
\text { prostředí }\end{array}$ & $53,6 \%$ \\
\hline $\begin{array}{l}\text { Přeshraniční spolupráce } \\
\text { Slovenská republika - Česká } \\
\text { republika 2007 - 2013 }\end{array}$ & $\begin{array}{l}\text { Rozvoj podnikatelského a } \\
\text { inovačního prostředí }\end{array}$ & $65,3 \%$ \\
\hline $\begin{array}{l}\text { Přeshraniční spolupráce Rakousko } \\
\text { - Česká republika 2007 - 2013 }\end{array}$ & $\begin{array}{l}\text { Infrastruktura a služby spojené } \\
\text { s podnikáním a inovacemi }\end{array}$ & $61,2 \%$ \\
\hline $\begin{array}{l}\text { Přeshraniční spolupráce Česká } \\
\text { republika - Svobodný stát } \\
\text { Bavorsko 2007 - 2013 }\end{array}$ & $\begin{array}{l}\text { Hospodářská spolupráce a } \\
\text { rozvoj ekonomického sektoru }\end{array}$ & $58,9 \%$ \\
\hline $\begin{array}{l}\text { Program na podporu přeshraniční } \\
\text { spolupráce mezi Českou } \\
\text { republikou - Svobodným státem } \\
\text { Sasko 2007 - 2013 }\end{array}$ & $\begin{array}{l}\text { Hospodářská kooperace a } \\
\text { rozvoj příhraničních } \\
\text { hospodářských struktur }\end{array}$ & $55,4 \%$ \\
\hline
\end{tabular}

Zdroj: Národní orgán pro koordinaci Ministerstva pro místní rozvoj $\check{C} R$.

Jediným národním tematickým operačním programem, který je zaměřen na rozvoj MSP, je Operační program Podnikání a inovace. Konkrétně je zaměřen na podporu rozvoje podnikatelského prostředí a podporu přenosu výsledků výzkumu a vývoje do podnikatelské praxe. ${ }^{4}$ Podporuje vznik nových a rozvoj stávajících firem, jejich inovační potenciál a využívání moderních technologií a obnovitelných zdrojů energie. Umožňuje zkvalitňování infrastruktury a služeb pro podnikání a navazování spolupráce mezi podniky a vědeckovýzkumnými institucemi. Žádat o podporu mohou podnikatelé, sdružení podnikatelů, výzkumné instituce, vysoké školy a ostatní vzdělávací instituce, neziskové organizace, fyzické osoby, územní samosprávné celky a jimi zrrizované a zakládané organizace, CzechInvest a CzechTrade. Operační program Podnikání a inovace obsahuje 6 tematických prioritních os rozdělujících operační program na logické celky, a ty jsou dále konkretizovány prostřednictvím tzv. oblastí podpor, které vymezují, jaké typy projektů mohou být v rámci př́ślušné prioritní osy podpořeny. Jedná se o prioritní osu Vznik firem, Rozvoj firem, Efektivní energie, Inovace, Prostředí pro podnikání a inovace a Služby pro rozvoj podnikání. V rámci ostatních národních tematických operačních programů je účast MSP velmi omezena, jedná se především o sekundární finanční pomoc.

\section{Závěr}

Stávající dotační struktura EU obsahuje 9 zásadních dotačních zdrojů, do kterých mohou české MSP a organizace podporující rozvoj MSP předkládat své projekty. Každý dotační zdroj je koncipován a zaměřen jiným způsobem. Značným problémem je však fakt, že každý ze zmíněných dotačních zdrojů je řízen odlišným způsobem. Konkrétně se jedná o to, že administrace projektů probíhá v odlišných informačních systémech, způsoby monitoringu

\footnotetext{
${ }^{4}$ Ministerstvo prümyslu a obchodu, http://www.mpo.cz/dokument77958.html
} 
a reporting vůči řídícím orgánům a zprostředkujícím subjektům jsou zcela odlišné, míra kofinancování je rozdílná, každý z dotačních zdrojů má nastavený jiný systém pro nákup externích služeb a dodávek podléhající Zákonu č. 137/2006 Sb. o veřejných zakázkách. Každý z dotačních zdrojů má také vytvořenu odlišnou strukturu prováděcí dokumentace včetně metodických příruček pro žadatele a př́ijemce. Všechny zmíněné informace tvoří základní informační rámec pro potenciální předkladatele projektů z řad MSP. Je zřejmé, že nároky kladené na MSP při předkládání projektových záměrů, jsou značné a mnoho $\mathrm{z}$ nich může informační náročnost těchto projektů odradit. Tento článek měl být námětem $\mathrm{k}$ zamyšlení pro všechny zainteresované instituce zapojené do tvorby strategie podpory MSP skrze evropské dotační zdroje, jak k této problematice přistupovat a zároveň návodem pro MSP, kam směřovat své rozvojové projekty v rámci evropských dotačních možností.

\title{
Literatura:
}

[1] MAREK, D., KANTOR, T. (2009): Příprava a řízení projektů strukturálních fondů Evropské unie. Brno: Společnost pro odbornou literaturu - barrister\&Principal.

[2] CHVOJKOVÁ, A., KVĚTOŇ, V. a kol. (2007): Finanční prostředky fondů EU v programovacím období 2007 - 2013. Praha: IREAS, Institut pro strukturální politiku, o.p.s.

[3] Operační program přeshraniční spolupráce CZ - PL 2007 - 2013. [online]. Dostupný z <http://www.cz-pl.eu/programovy-dokument.html>

[4] Operační program preshraniční spolupráce SK - CZ 2007 - 2013. [online]. Dostupný z <http://www.sk-cz.eu/sk/uvodna-stranka/materialy-a-dokumenty-materialy-adokumenty/>

[5] Strukturální fondy EU. [online]. Dostupný $\mathrm{z} \quad \leq \mathrm{http}$ ://www.strukturalnifondy.cz/Programy-2007-2013/Evropska-uzemni-spoluprace>

[6] <http://www.ec.europa.eu $>$

[7] VEBER, J., SRPOVÁ, J. A kol. (2008): Podnikání malé a střední firmy. Praha: Grada Publishing

[8] PELTRÁM, A. (2009): Evropská integrace a Česká republika. Praha: Grada Publishing

Klasifikace JEL: H29

\author{
Ing. Jan Urbánek \\ Odborný asistent, Katedra marketingu \\ Obchodně podnikatelská fakulta \\ Slezská univerzita v Opavě \\ Univerzitní náměstí 1934/3, 73340 Karviná \\ urbanek@opf.slu.cz
}

